Onggo, T.M. $\cdot$ Kusumiyati $\cdot A$. Nurfitriana

\title{
Pengaruh penambahan arang sekam dan ukuran polybag terhadap pertumbuhan dan hasil tanaman tomat kultivar 'Valouro' hasil sambung batang
}

\section{The effect of the addition of rice husk charcoal and polybag size on growth and yield of grafted tomato plant Valouro cultivar}

Diterima : 15 Februari 2017/Disetujui : 15 Maret 2017 / Dipublikasikan : 30 Maret 2017

CDepartment of Crop Science, Padjadjaran University

\begin{abstract}
Beef tomato is a high economic value horticultural commodity, the plant is sensitive to soilborne disease. Grafting technology is done to protect the plant toward soilborne disease to be possible to produced fruit in good quality. Planting in polybag inside plastic house was intended for planting tomatoes continuously. Rice husk charcoal as a soil amendment applied to improved the Jatinangor Inceptisol soil. The purpose of this research was to study the composition of the addition of rice husk charcoal and polybag size to improved growth and yield of grafted beef tomato, Valouro cultivars. The research was carried out in August 2015 up to January 2016 in the plastic house of Controlled Culture Laboratory of the Faculty of Agriculture, University of Padjadjaran, Jatinangor. The experimental design used was factorial randomize block design, consisted of two factors and three replications. The first factor was the polybag size: $30 \times 35 \mathrm{~cm}, 35 \times 35 \mathrm{~cm}$, and $35 \times$ $40 \mathrm{~cm}$. The second factor was the addition of rice husk charcoal: without the additional (controlled), $10 \%(\mathrm{v} / \mathrm{v})$, and $20 \%(\mathrm{v} / \mathrm{v})$. The results showed that there were no interaction effects between the two treatment on all parameters observed. The biggest polybag size $(35 \times 40 \mathrm{~cm})$ increased the plant heigh and percentage of number and weight of A class fruit quality and decreased the percentage of number and weight of $\mathrm{C}$ class fruit quality. The addition of rice husk charcoal $20 \%(\mathrm{v} / \mathrm{v})$ affected on smaller stem diameters.
\end{abstract}

Keywords: Beef tomato · Growth · Yield · Fruit quality

\footnotetext{
Dikomunikasikan oleh Yudithia Maxiselly

Onggo, T.M. · Kusumiyati ·A. Nurfitriana

${ }^{1}$ Departemen Budidaya, Fakultas Pertanian, Unpad

${ }^{2}$ Mahasiswa Program Studi Agroteknologi, Fakultas

Pertanian, Unpad

Korespondensi: tinong2002@yahoo.com
}

Sari Tanaman tomat beef merupakan komoditas hortikultura bernilai ekonomi tinggi yang peka terhadap penyakit tular-tanah. Penerapan teknologi sambung batang dilakukan untuk melindungi tanaman dari serangan penyakit tersebut sehingga dapat menghasilkan buah dengan kualitas yang optimal. Penanaman dalam polybag dimaksudkan agar rumah plastik dapat digunakan untuk penanaman tomat secara kontinyu. Arang sekam sebagai salah satu bahan pembenah tanah diaplikasikan untuk perbaikan tanah Inceptisol Jatinangor. Tujuan dari penelitian ini adalah untuk mendapatkan komposisi penambahan bahan pembenah arang sekam dan ukuran polybag yang berpengaruh dalam meningkatkan pertumbuhan dan hasil tanaman tomat beef kultivar Valouro hasil sambung batang. Penelitian dilaksanakan pada bulan Agustus 2015 sampai Januari 2016 di dalam rumah plastik Laboratorium Kultur Terkendali, Fakultas Pertanian, Universitas Padjadjaran, Jatinangor. Penelitian ini menggunakan metode Rancangan Acak Kelompok (RAK) faktorial yang terdiri atas dua faktor dan tiga ulangan. Faktor pertama yaitu ukuran polybag: $30 \times 35 \mathrm{~cm}, 35 \times 35 \mathrm{~cm}$, dan $35 \times 40 \mathrm{~cm}$; faktor kedua yaitu penambahan bahan pembenah arang sekam: tanpa penambahan (kontrol), 10\% (v/v) arang sekam, dan 20\% (v/v) arang sekam. Hasil penelitian menunjukkan bahwa tidak terjadi interaksi antara perlakuan ukuran polybag dan penambahan arang sekam terhadap semua parameter pengamatan. Ukuran polybag terbesar $(35 \times 40 \mathrm{~cm})$ berpengaruh meningkatkan tinggi tanaman dan persentase jumlah dan bobot buah kualitas A sebaliknya menurunkan persentase jumlah dan bobot buah kualitas C, sedangkan pada penambahan arang sekam 20\% (v/v) diameter batang menjadi lebih kecil.

Kata kunci : Tomat beef - Pertumbuhan - Hasil . Kualitas buah 


\section{Pendahuluan}

Tomat (Lycopersicon esculentum Mill.) merupakan salah satu komoditas hortikultura yang paling banyak dikonsumsi di dunia dan bernilai ekonomi tinggi. Buah tomat dimanfaatkan sebagai sumber vitamin dan mineral. Buah tomat umumnya dikonsumsi dalam bentuk segar, dapat juga dikonsumsi dalam bentuk olahan.

Tomat beef merupakan salah satu varietas tomat eksklusif yang dapat menjadi peluang bisnis. Ukuran buah yang besar (170 g hingga $227 \mathrm{~g}$ per-buah) (Hochmuth and Hochmuth, 2012) serta tekstur keras dan renyah adalah karakteristik utama bagi varietas ini, selain memiliki harga jual yang tinggi dan stabil, buah juga memiliki daya simpan lebih lama. Pemanfaatan tomat beef secara umum adalah sebagai sayuran segar, garnish atau penghias makanan dan irisan pada burger.

Salah satu kendala utama penanaman tanaman tomat beef di Indonesia adalah tanaman peka terhadap penyakit tular tanah (soil-borne disease) yaitu penyakit layu yang disebabkan oleh bakteri Ralstonia solanacearum atau jamur Fusarium oxysporium. Peningkatan kualitas tanaman dan hasil yang seragam dapat dihasilkan dengan teknologi hidroponik tetapi membutuhkan modal yang cukup besar.

Kepekaan tomat beef terhadap penyakit tular tanah dapat diatasi secara efektif oleh penggunaan teknik sambung batang. Pada teknik sambung batang, batang bawah secara spesifik memberikan pengaruh resistensi terhadap penyakit tular tanah dan nematoda, sedangkan sambungan pada batang atas berfungsi dalam mempertahankan hasil produksi tanaman (Kubota, et al., 2008). Penelitian yang dilakukan Rivard and Louws (2006) menunjukkan bahwa penggunaan teknik sambung batang menggunakan batang bawah yang resisten mampu mengurangi layu bakteri secara signifikan serta mampu menjaga kualitas buah tomat tetap baik meskipun ditanam di tanah yang terinfeksi. Saat ini perusahaan benih 'Rijk Zwaan' telah memasarkan bibit sambung batang dari berbagai kultivar tomat di Indonesia.

Penanaman tanaman tomat dalam rumah plastik membutuhkan rotasi tanam karena tanah dan lahan yang dipakai tidak berpindah, oleh karena itu penggunaan wadah media tanam berupa polybag dapat dijadikan sebagai alternatif untuk menjaga produktivitas lahan di dalam rumah plastik terhadap tanaman tomat. Penggunaan polybag ini bertujuan untuk dapat mengganti media, sehingga penanaman tomat dalam rumah plastik dapat dilakukan secara terus menerus dan meminimalisir perpindahan penyakit melalui tanah.

Perakaran merupakan sandaran utama pada tanaman tomat dalam menunjang aerasi fotosintat dan kerja hormon tumbuhan. Keseimbangan antara perakaran dan tunas tanaman sulit terjadi ketika sistem perakaran dibatasi dalam volume media tumbuh yang sempit. Pertumbuhan dan perkembangan tanaman dipengaruhi oleh ukuran media dan perpanjangan batas akar (NeSmith and Duval, 1998). Menurut Agoes (1994), untuk menghasilkan media tanam yang sesuai dengan perakaran tanaman memerlukan kombinasi beberapa bahan dan disesuaikan dengan jenis tanaman. Penggunaan ukuran dan komposisi media tanam yang sesuai akan mempengaruhi jangka waktu daya tumbuh tanaman.

Meta-analisis yang dilakukan oleh Poorter et.al (2012) menunjukkan adanya pengaruh ukuran pot terhadap pertumbuhan tanaman. Penggandaan ukuran media mampu meningkatkan $43 \%$ biomassa tanaman. Penelitian oleh Wasonowati (2010) menunjukkan bahwa perlakuan ukuran polybag berpengaruh nyata terhadap jumlah daun, bobot basah dan bobot kering batang dan daun pada tanaman tomat. Hasil pengujian terhadap polybag dengan tiga ukuran $30 \times 30 \mathrm{~cm}, 30 \times 40 \mathrm{~cm}$, dan $40 \times 40 \mathrm{~cm}$ menunjukkan bobot basah dan bobot kering tertinggi terdapat pada ukuran polybag terbesar 40 x $40 \mathrm{~cm}$. Ukuran polybag yang biasa digunakan pada penanaman tomat dengan sistem hidroponik di Jatinangor adalah $30 \mathrm{~cm} x$ $30 \mathrm{~cm}$.

Penyediaan campuran media tanam yang sesuai dengan syarat tumbuh tanaman sangat penting untuk kualitas produksi tanaman hortikultura. Secara umum, tanah Inceptisols seperti yang ada di Jatinangor memiliki kesuburan dan sifat kimia yang relatif rendah tetapi masih dapat diupayakan untuk ditingkatkan dengan penanganan dan teknologi yang tepat (Sudirja, dkk., 2007). Arang sekam merupakan bahan pembenah tanah yang mampu memperbaiki sifat-sifat tanah dalam upaya rehabilitasi lahan dan memperbaiki pertumbuhan tanaman (Supriyanto dan Fiona, 2010). Penambahan arang sekam ke dalam 
media tanam tanah Inceptisols yang memiliki drainase buruk dapat meningkatkan ruang pori total dan mempercepat drainase air tanah (Kusuma dkk., 2013).

Penelitian mengenai penambahan arang sekam ke dalam media tanam sebagai pembenah tanah dengan perbandingan 1:1 oleh Gustia (2013), menunjukkan hasil tinggi tanaman, jumlah daun, panjang daun, lebar daun, bobot basah, dan bobot konsumsi tertinggi pada tanaman sawi (Brassica juncea L.). Sementara itu, penelitian oleh Syahid, dkk. (2014) menunjukkan terjadi interaksi antara perlakuan arang sekam dan kompos kotoran kambing terhadap tinggi tanaman, bobot segar hasil, dan bobot kering tanaman segau (Vernonia cinerea) saat panen.

Penambahan bahan pembenah tanah arang sekam dan ukuran polybag yang tepat perlu dikaji lebih lanjut pada penanaman tomat beef kultivar Valouro hasil sambung batang dalam rumah plastik untuk melihat pengaruh yang lebih baik pada pertumbuhan, hasil dan kualitas hasil tanaman.

\section{Bahan dan Metode}

Penelitian dilakukan di rumah plastik Laboratorium Kultur Terkendali Fakultas Pertanian Universitas Padjadjaran, dengan ketinggian $730 \mathrm{~m}$ di atas permukaan laut, dilaksanakan dari bulan Agustus 2015 sampai dengan Januari 2016.

Rancangan percobaan yang digunakan adalah Rancangan Acak Kelompok (RAK) pola faktorial dengan dua faktor dan tiga ulangan. Faktor pertama adalah ukuran polybag $(\mathrm{P})$ terdiri dari tiga taraf, yaitu $\mathrm{p}_{1}(30 \times 35 \mathrm{~cm}), \mathrm{p}_{2}(35 \times 35$ $\mathrm{cm})$, dan $\mathrm{p}_{3}(35 \times 40 \mathrm{~cm})$. Faktor kedua adalah volume penambahan bahan pembenah tanah arang sekam (A) terdiri dari tiga taraf, yaitu ao (tanpa arang sekam), a (arang sekam 10\% $(\mathrm{v} / \mathrm{v})$ ), dan $\mathrm{a}_{2}$ (arang sekam 20\% (v/v)). Setiap plot terdiri dari 10 tanaman. Jumlah sampel tiap plot 4 tanaman untuk pengamatan pertumbuhan dan data hasil diambil dari keseluruhan tanaman dalam plot.

Bibit tomat yang digunakan adalah Kultivar Valouro hasil sambung batang dari perusahaan benih 'Rijk Zwaan', sedangkan media tanam terdiri dari campuran tanah Inceptisol dan kompos (70:30) v/v, dan arang sekam sesuai perlakuan. Selama jangka waktu tanam diaplikasikan pupuk dan pestisida, antara lain: pupuk NPK mutiara 16:16:16 dan 25:7:7, pupuk "Grow More", $\mathrm{KNO}_{3}$ dan pupuk larutan Jatinangor 2, insektisida dengan bahan aktif metomil dan acetamiprid, serta fungisida berbahan aktif fenarimol dan mefenomax/ mankozeb. Pengamatan hasil pada penelitian ini dilakukan hingga produksi 8 tandan buah per tanaman.

Pengamatan pertumbuhan meliputi: tinggi tanaman $(\mathrm{cm})$, jumlah daun, dan diameter batang $(\mathrm{cm})$. Pengamatan hasil dan kualitas meliputi: jumlah buah (butir) dan bobot buah (g) per plot, persentase jumlah dan bobot buah layak pasar (LP) dan tidak layak pasar (TLP) dan persentase berdasarkan kelas kualitas buah. Pengaruh perlakuan diuji dengan uji $\mathrm{F}$ dengan taraf nyata 5\%, sedangkan untuk menguji perbedaan nilai rata-rata perlakuan dilakukan dengan uji Duncan pada taraf nyata 5\%.

\section{Hasil dan Pembahasan}

Pengamatan Pertumbuhan Tanaman. Data hasil analisis statistik menunjukkan tidak terdapat interaksi antara perlakuan ukuran polybag dan penambahan arang sekam pada semua komponen pertumbuhan dan hasil, namun terdapat pengaruh mandiri dari masing-masing faktor.

Hasil analisis data pada Tabel 1 . menunjukkan bahwa pada pengamatan 2 - 8 MST (minggu setelah tanam) perubahan tinggi tanaman baru terlihat pada umur 8 MST, diduga karena hara tanaman yang berasal dari kompos baru optimal diserap akar tanaman pada waktu pengamatan tersebut.

Polybag ukuran terbesar memperlihatkan tanaman yang lebih tinggi dibandingkan kedua ukuran polybag lainnya yang lebih kecil. Perbedaan yang signifikan dapat terjadi pada perlakuan ukuran polybag karena semakin besar polybag yang digunakan, maka akan semakin besar pula muatan volume media di dalamnya sehingga perakaran tanaman lebih mudah berkembang dan daya topang tanah terhadap tanaman lebih kuat. Pada polybag yang lebih besar juga memiliki volume campuran kompos yang lebih banyak, sehingga kandungan media tanam secara biologis dan kimiawinya juga lebih baik dibandingkan pada polybag yang lebih kecil ukurannya (Ghorbani, dkk., 2008).

Pada pengamatan diameter batang (Tabel 2.) perlakuan ukuran polybag tidak berpengaruh 
secara nyata diduga karena adanya kecenderungan tanaman percobaan untuk bersifat dominan pada pertambahan tinggi tanaman sehingga pengaruhnya kurang terlihat pada pembesaran diameter batang. Dominansi pertambahan tinggi tanaman tersebut kemudian menekan aktivitas pembesaran diameter batang sehingga pengaruh ukuran polybag hanya terlihat nyata terhadap pertambahan tinggi tanaman.

Tabel 1. Pengaruh penambahan arang sekam dan ukuran polybag terhadap pertumbuhan tinggi tanaman tomat 2-8 MST

\begin{tabular}{lcccc}
\hline \hline \multirow{2}{*}{ Perlakuan } & \multicolumn{5}{c}{ Tinggi Tanaman (cm) } \\
\cline { 2 - 5 } & 2 MST & 4MST & 6MST & 8MST \\
\hline Ukuran Polybag & & & & \\
$30 \times 35$ cm & 43,3 & 85,8 & 133,6 & 164,1 a \\
35 x 35 cm & 44,3 & 87,2 & 135,6 & 164,9 a \\
35 x 40 cm & 43,6 & 86,8 & 137,7 & $174,4 \quad b$ \\
\hline Arang Sekam & & & & \\
$0 \%$ & 43,0 & 85,8 & 135,4 & 166,8 \\
$10 \%$ & 43,5 & 87,3 & 135,4 & 169,7 \\
$20 \%$ & 44,7 & 86,7 & 136,1 & 166,9 \\
\hline \hline
\end{tabular}

Keterangan: Nilai rata-rata yang diikuti huruf yang sama pada kolom yang sama menunjukkan tidak berbeda nyata

Perlakuan arang sekam tidak memberikan perbedaan nyata terhadap tinggi tanaman, hal tersebut terjadi karena penambahan arang sekam memiliki pengaruh yang lebih besar terhadap peningkatan perkembangan akar dibandingkan bagian tajuknya (Irawan dan Kafiar, 2015). Arang sekam berpengaruh terhadap diameter batang, pada perlakuan penambahan arang sekam terbanyak, memperlihatkan diameter batang dengan ukuran lingkar terkecil jika dibandingkan hasil penambahan arang yang lebih sedikit dan tanpa penambahan. Penambahan arang sekam seharusnya bersifat menguntungkan karena dapat memperbaiki sifat fisik tanah, akan tetapi karena sifatnya yang porous yang menjadi dugaan bahwa tanaman mengalami kekurangan air sehingga pada penambahan arang sekam terbanyak menunjukkan pertumbuhan diameter batang lebih kecil secara nyata.

Pertumbuhan dan perkembangan tanaman budidaya seringkali dibatasi oleh air. Respon tumbuhan terhadap kekurangan air dapat dilihat pada aktivitas metabolisme, morfologi, tingkat pertumbuhan, ataupun produktivitas tanaman tersebut. Pertumbuhan sel merupakan fungsi tanaman yang paling sensitif terhadap kekurangan air. Kekurangan air akan mempengaruhi turgor sel sehingga akan mengurangi pengembangan sel, sintesis protein dan sintesis dinding sel (Solichatun, dkk. 2005). Penurunan akumulasi biomassa akibat cekaman air untuk setiap jenis tanaman besarnya tidak sama. Keberadaan air juga berpengaruh langsung terhadap aktivitas fotosintesis sehingga erat kaitannya dalam menunjang pertumbuhan dan hasil tanaman.

Tabel 2. Pengaruh penambahan arang sekam dan ukuran polybag terhadap diameter batang tanaman tomat 8 MST

\begin{tabular}{lc}
\hline \hline Perlakuan & $\begin{array}{c}\text { Diameter Batang 8 MST } \\
(\mathbf{c m})\end{array}$ \\
\hline Ukuran Polybag & \\
$30 \times 35 \mathrm{~cm}$ & 0,83 \\
$35 \times 35 \mathrm{~cm}$ & 0,84 \\
$35 \times 40 \mathrm{~cm}$ & 0,85 \\
\hline Arang Sekam & \\
$0 \%$ & $0,86 \mathrm{~b}$ \\
$10 \%$ & $0,87 \mathrm{~b}$ \\
$20 \%$ & $0,79 \mathrm{a}$ \\
\hline \hline
\end{tabular}

Keterangan: Nilai rata-rata yang diikuti huruf yang sama pada kolom yang sama menunjukkan tidak berbeda nyata menurut Uji Lanjut Jarak Berganda Duncan pada taraf 5\%

Pengamatan Hasil dan Kualitas Hasil. Berdasarkan data pada Tabel 3. dan Tabel 4. menunjukkan bahwa jumlah buah dan bobot buah total per plot dan buah layak pasar (LP) serta tidak layak pasar (TLP) tidak dipengaruhi secara nyata oleh ukuran polybag, penambahan arang sekam maupun interaksi keduanya. Data pada Tabel 3. memperlihatkan bahwa genetis tanaman menunjukkan penampakkan hasil yang seragam meskipun jumlah maupun bobot buah pada tanaman percobaan hingga pengamatan panen pada tandan ke- 8 belum mencapai target potensi genetik tanaman.

Belum tercapainya target hasil sesuai potensi genetik dapat disebabkan oleh faktor eksternal yaitu, pengaruh lingkungan maupun cara budidaya. Salah satu keunggulan tomat beef kultivar Valouro yaitu memiliki resistensi terhadap virus namun disamping itu juga memiliki kelemahan yaitu bersifat responsif terhadap pupuk jika dibandingkan dengan jenis tomat beef lainnya, sehingga penerapan standar budidayanya lebih intensif. Lingkungan tumbuh tanaman seperti ketinggian tempat dan 
temperatur juga mempengaruhi pertumbuhan dan umur tanaman tomat beef.

Tabel 3. Pengaruh penambahan arang sekam dan ukuran polybag terhadap jumlah dan bobot buah total per plot

\begin{tabular}{lcc}
\hline \hline Perlakuan & $\begin{array}{c}\text { Jumlah } \\
\text { Buah/ Plot }\end{array}$ & $\begin{array}{c}\text { Bobot Buah/ } \\
\text { Plot (kg) }\end{array}$ \\
\hline Ukuran Polybag & & \\
$30 \times 35 \mathrm{~cm}$ & 103,33 & 12,51 \\
$35 \times 35 \mathrm{~cm}$ & 99,88 & 11,97 \\
$35 \times 40 \mathrm{~cm}$ & 109,33 & 14,11 \\
\hline Arang Sekam & & \\
$0 \%$ & 108,68 & 13,16 \\
$10 \%$ & 105,22 & 12,93 \\
$20 \%$ & 98,64 & 12,50 \\
\hline \hline
\end{tabular}

Keterangan: Nilai rata-rata yang tidak diikuti huruf, menyatakan bahwa uji F tidak menunjukkan perbedaan nyata pada taraf $5 \%$

Ketidakseimbangan kondisi fisiologis yang terjadi selama percobaan akibat lingkungan yang kurang mendukung tersebut berpengaruh langsung terhadap hasil buah layak dan tidak layak pasar serta berpengaruh tidak langsung terhadap jumlah dan bobot buah total yang dihasilkan (Tabel 4.). Salah satu penyebab utamanya, diduga karena adanya pengaruh kelembaban dan temperatur yang fluktuatif sepanjang proses pembuahan pada umur $4-14$ MST (pengamatan hingga 8 tandan). Kondisi lingkungan daerah Jatinangor dengan temperatur yang cukup tinggi mempercepat proses transpirasi dan respirasi tanaman sehingga tanaman sempat mengalami cekaman kekeringan pada fase pembesaran buah yang rentan cekaman tersebut. Kandungan air yang tidak terpenuhi pada tanaman mengurangi penyerapan dan pelepasan kalsium pada saat pembesaran buah sehingga buah mengalami defisiensi kalsium dan meninggalkan bekas berupa Blossom-end Rot (BER) (Fake, 2010) yang berpengaruh langsung terhadap buah tidak layak pasar yang dihasilkan.

Tingginya persentase buah tidak layak pasar (mencapai 30\%) yang dihasilkan dipengaruhi terutama oleh adanya gangguan fisiologis pada buah selama percobaan berupa BER yang berpengaruh secara nyata mengurangi jumlah dan bobot buah layak pasar (LP) yang dihasilkan.

Tabel 4. Pengaruh penambahan arang sekam dan ukuran polybag terhadap persentasejumlah dan bobot buah layak dan tidak layak pasar per-plot

\begin{tabular}{lcccc}
\hline \hline \multirow{2}{*}{ Perlakuan } & \multicolumn{2}{c}{$\begin{array}{c}\text { Jumlah Buah } \\
(\mathbf{\%})\end{array}$} & \multicolumn{2}{c}{$\begin{array}{c}\text { Bobot Buah } \\
(\%)\end{array}$} \\
\cline { 2 - 5 } & LP & TLP & LP & TLP \\
\hline Ukuran Polybag & & & & \\
$30 \times 35 \mathrm{~cm}$ & 62,23 & 37,77 & 71,57 & 28,43 \\
$35 \times 35 \mathrm{~cm}$ & 60,70 & 39,30 & 70,33 & 29,67 \\
$35 \times 40 \mathrm{~cm}$ & 67,73 & 32,27 & 75,00 & 25,00 \\
\hline Arang Sekam & & & & \\
$0 \%$ & 62,27 & 37,73 & 71,67 & 28,33 \\
$10 \%$ & 62,03 & 37,97 & 70,87 & 29,13 \\
$20 \%$ & 66,37 & 33,63 & 74,37 & 25,63 \\
\hline \hline
\end{tabular}

Keterangan : Nilai rata-rata tidak diikuti huruf, menyatakan bahwa uji $\mathrm{F}$ tidak menunjukkan perbedaan nyata pada taraf 5\%; LP= Layak Pasar; TLP= Tidak Layak Pasar

Persentase serangan BER dengan kisaran $30 \%$ menunjukkan terjadinya pengaruh BER yang cenderung merata pada semua perlakuan. BER menyerang tanaman percobaan secara menyeluruh dan tidak mengakibatkan pengaruh secara spesifik pada perlakuan manapun.

Data pada Tabel 5. Menunjukkan bahwa didapatkan pengaruh mandiri pada perlakuan ukuran polybag. Polybag terbesar memberikan

Tabel 5. Pengaruh penambahan arang sekam dan ukuran polybag terhadap persentase jumlah dan bobot buah

\begin{tabular}{|c|c|c|c|c|c|c|}
\hline \multirow{2}{*}{$\begin{array}{l}\text { Perlakuan } \\
\text { Kelas Kualitas }\end{array}$} & \multicolumn{3}{|c|}{ Jumlah Buah (\%) } & \multicolumn{3}{|c|}{ Bobot Buah (\%) } \\
\hline & $\mathbf{A}$ & B & $\mathrm{C}$ & $\mathbf{A}$ & B & $\mathrm{C}$ \\
\hline \multicolumn{7}{|l|}{ Ukuran Polybag } \\
\hline $30 \times 35 \mathrm{~cm}$ & $18,27 \mathrm{a}$ & 42,33 & $39,93 \mathrm{~b}$ & 23,25 a & 43,64 & $34,10 \mathrm{~b}$ \\
\hline $35 \times 35 \mathrm{~cm}$ & 17,10 a & 41,08 & $44,23 \mathrm{~b}$ & 22,29 a & 42,84 & $37,14 \mathrm{~b}$ \\
\hline $35 \times 40 \mathrm{~cm}$ & $25,16 \mathrm{~b}$ & 46,75 & 27,65 a & $29,99 \mathrm{~b}$ & 48,95 & $23,40 \mathrm{a}$ \\
\hline \multicolumn{7}{|l|}{ Arang Sekam } \\
\hline $0 \%$ & 19,59 & 43,39 & 37,59 & 24,60 & 45,77 & 32,65 \\
\hline $10 \%$ & 21,20 & 39,35 & 38,69 & 26,77 & 40,90 & 32,82 \\
\hline $20 \%$ & 19,73 & 47,43 & 35,53 & 24,17 & 48,76 & 29,17 \\
\hline
\end{tabular}

Keterangan: Nilai rata-rata yang diikuti huruf yang sama pada kolom yang sama menunjukkan tidak berbeda nyata menurut Uji Lanjut Jarak Berganda Duncan pada taraf 5\% 
hasil persentase tertinggi terhadap bobot dalam kualitas buah kelas A. Polybag terkecil menunjukkan hasil bobot yang tidak berbeda nyata dengan polybag ukuran sedang. Jika dilihat dari jumlah dan bobot buah yang dihasilkan, perlakuan polybag terbesar juga menunjukkan persentase yang lebih tinggi pada kelas kualitas buah A secara signifikan serta memperlihatkan persentase jumlah dan bobot buah terkecil dalam kualitas buah kelas $C$ yang berbeda nyata jika dibandingkan dengan kedua perlakuan lainnya.

Jumlah media yang lebih banyak pada polybag terbesar mampu menyediakan ruang untuk perkembangan akar yang lebih optimal dibandingkan perlakuan ukuran polybag yang lebih kecil, oleh karena itu, semakin besar ukuran polybag yang digunakan dalam penelitian ini, maka penyerapan hara cenderung lebih baik karena ditunjang oleh penyebaran akar yang lebih mudah untuk berkembang. Penyerapan hara yang optimal pada tanaman secara langsung mempengaruhi persentase jumlah dan kelas kualitas buah yang dihasilkan.

Perlakuan arang sekam secara mandiri tidak berpengaruh terhadap persentase jumlah maupun bobot buah dalam kelas apapun, hal ini diduga karena arang sekam adalah bahan pembenah yang steril sehingga tidak memuat kandungan hara yang dapat menunjang tanaman dalam menghasilkan kualitas buah berbeda.

Wasonowati (2010), menyatakan bahwa produksi tomat yang lebih tinggi bisa didapatkan jika ditunjang oleh pertumbuhan vegetatif yang optimal antara lain ketersediaan hara dan faktor tumbuh lainnya. Berdasarkan hasil analisis statistik pada data pertumbuhan tanaman (Tabel 1.), pengaruh tinggi tanaman sejalan hasilnya dengan persentase jumlah dan bobot buah tiap kelas kualitas. Kelas kualitas buah yang dihasilkan pada tanaman tomat dipengaruhi oleh kombinasi antara potensi genetik, iklim, dan cara budidaya (Sinha et al., 2010).

Polybag dengan ukuran terbesar memiliki kandungan campuran bahan organik berupa kompos (v/v) yang lebih banyak dibandingkan ukuran polybag lainnya. Semakin besar volume media yang digunakan, maka semakin meningkatkan sistem perkembangan akar, artinya penyerapan air dan unsur hara akan lebih optimal yang berdampak pada pertumbuhan dan hasil tanaman percobaan.
Kompos mampu menggemburkan tanah sehingga dapat mempermudah perkembangan akar dan meningkatkan kemampuannya dalam penyerapan hara secara optimal (Samekto, 2006). Penyerapan hara yang lebih optimal pada perlakuan ukuran polybag terbesar tersebut mampu memperlihatkan peningkatan persentase jumlah dan bobot buah kelas A secara nyata dibandingkan perlakuan ukuran polybag lain yang lebih kecil.

\section{Kesimpulan dan Saran}

1. Tidak terdapat interaksi antara perlakuan ukuran polybag dengan penambahan arang sekam terhadap semua variabel pada pengamatan pertumbuhan dan hasil tanaman tomat beef kultivar Valouro hasil sambung batang.

2. Perlakuan ukuran polybag terbesar pada penelitian ini $(35 \mathrm{~cm} \times 40 \mathrm{~cm})$ menghasilkan tanaman yang lebih baik pada komponen pertumbuhan tanaman yaitu tinggi tanaman serta komponen hasil tanaman yaitu persentase jumlah dan bobot buah kualitas A serta menurunkan persentase jumlah dan bobot buah kualitas C dibandingkan perlakuan ukuran polybag yang lebih kecil.

Saran. Gangguan fisiologis Blossom-end Rot (BER) pada tanaman percobaan menjadi gangguan dengan intensitas tertinggi yang mempengaruhi hasil percobaan sehingga perlu dilakukan pemilihan kultivar yang toleran terhadap gangguan BER serta perbaikan teknik budidaya untuk mencapai keseimbangan fisiologis tanaman.

\section{Daftar Pustaka}

Agoes, D. 1994. Aneka Jenis Media Tanam dan Penggunaannya. Penebar Swadaya, Jakarta.

Fake, C. 2010. Managing blossom-end rot in tomatoes and peppers. Cooperative Extension, University of California.

Ghorbani, R., A. Koocheki, M. Jahan, dan G.A. Asadi. 2008. Impact of organic amendments and compost extracts on tomato production and storability in agroecologicalsystems. Agron. Sustain. Dev. (28): 307-311

Gustia, H. 2013. Pengaruh penambahan sekam bakar pada media tanam terhadap pertumbuhan dan produksi tanaman sawi 
(Brassica juncea 1.). E-Journal Widya Kesehatan dan Lingkungan. Vol. 1 (01): 12-17.

Hochmuth, G. J. and R. C. Hochmuth. 2012. Production of greenhouse tomatoes. Florida Greenhouse Vegetable Production Handbook, Vol 31.

Irawan, A. dan Y. Kafiar. 2015.Pemanfaatan cocopeat dan arang sekam padi sebagai media tanam bibit cempaka wasian (Elmerrilia ovalis). Pros. Semnas Masyarakat Biodiversitas Indonesia.Vol. 1 (4): 805-808.

Kubota, C., M. A. McClure, N. Kokalis-Burelle, M. G. Bausher, and E. N. Rosskopf. 2008. Vegetable grafting: History, use, and current technology status in North America. HortScience. Vol.43(6): 1664-1669.

Kusuma, A. H., M. Izzati, dan E. Saptiningsih. 2013. Pengaruh penambahan arang dan abu sekam dengan proporsi yang berbeda terhadap permeabilitas dan porositas tanah liat serta pertumbuhan kacang hijau (Vigna radiata L.). Bul. Anat. \& Fisiol. Vol. XXI(1): 1-9.

Poorter, H., J. Buhler, D. V. Dusschoten, J. Climent, and J. A. Postma. 2012. Pot size matters: a meta-analysis of the effects of rooting volume on plant growth. Journal Compilation by CSIRO, Functional Plant Biology Vol. 39 (839-850).

Rivard, C. and F. Louws. 2006. Grafting for disease resistance in heirloom tomatoes. North Carolina Cooperative Extension Service.

Samekto, R. 2006. Pupuk Kompos. PT. Intan Sejati. Klaten.
Sinha, N., Y. H. Hui, E. O. Evranuz, M. Siddiq, and J. Ahmed. 2010. Handbook of Vegetables and Vegetable Processing. Wiley-Blackwell. New Jersey.

Smith, N., D. Scott and J. R. Duval. 1998. The effect of container size. HortTechnology. Vol. October-December 8(4).

Solichatun, E. Anggarwulan, dan W. Mudyantini. 2005. Pengaruh Ketersediaan Air terhadap Pertumbuhan dan Kandungan Bahan Aktif Saponin Tanaman Ginseng Jawa (Talinum paniculatum Gaertn.). Biofarmasi 3 (2): 47-51.

Sudirja, R., M. A. Sholihin, dan S. Rosniawaty. 2007. Respons beberapa sifat kimia inceptisols asal rajamandala dan hasil bibit kakao (Theobroma cacao L.) melalui pemberian pupuk organik dan pupuk hayati. Universitas Padjadjaran.

Supriyanto dan F. Fiona. 2010. Pemanfaatan arang sekam untuk memperbaiki pertumbuhan semai jabon (Anthocephalus cadamba (Roxb.) Miq) pada media subsoil. J. Silvikultur Tropika, Vol. 01 (01): 24-28.

Syahid, A., G. Pituati, dan S. Kresnatita. 2013. Pemanfaatan arang sekam padi dan pupuk kandang untuk mendapatkan pertumbuhan dan hasil tanaman segau pada tanah gambut. J. Agri-peat, Vol. 5, No. 2.

Wasonowati, C. 2010. Peningkatan produksi dan kualitas tomat (Lycopersicon esculentum) dengan sistem budi daya hidroponik. Rekayasa, Vol. 3 (2): 83-89. 